\title{
NASA
}

Amea Recearch Center.

FACSIMILE TRANSMISSION

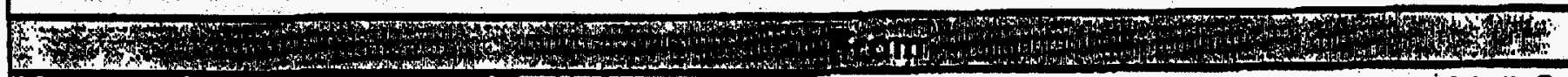
Name

Donna Lacy

Space Diractorate, M/S 200-7

NASA Ames Research Center

Moffett Fleld; CA 94035-1000

\section{Office Phone}

\section{Mall Address}

DOE $\mid E R / 61743-12$

(415) $604-5087$

Transmitting Fax

(415) 604-1165

\section{Mail Stop}

\begin{tabular}{l}
\hline Name \\
James Solomon \\
Contracting Officer \\
Program Acquieleton and \\
Aselotence. Division
\end{tabular}

\section{Office Phone}

(510) 637-1865

artion

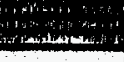

\section{Mall Address}

Departinent of Energy

Oakland Operations Office

1301 Clay Street

Oakland, CA 94612-5208

\section{Date}

$1 / 24 / 97$

\begin{tabular}{|l|ll}
\hline Offlce Phone & Rocolving Fax & $\begin{array}{l}\text { Pages } \\
\text { Ineluding Cover }\end{array}$ \\
$(510) 637-1865$ & (510) $637-2074$ & 5
\end{tabular}

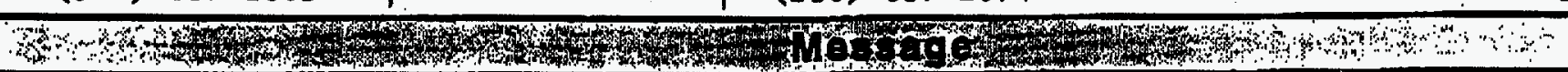

Subject: Technical Deliverablea for Incaragency Agreement No. DE-A103-94ER61743

Regerding your 1etter of June 6, 1996, the subject report for FY 1994-1996 was electron1cally sent by Brian Toon of Ames Research to' $P$. W. Lunn, Program Manager, per his request.

Per our phone conversation today, we are faxing this report to your office so your files will be complete: 


\section{DISCLAIMER}

This report was prepared as an account of work sponsored by an agency of the United States Government. Neither the United States Government nor any agency thereof, nor any of their employees, make any warranty, express or implied, or assumes any legal liability or responsibility for the accuracy, completeness, or usefulness of any information, apparatus, product, or process disclosed, or represents that its use would not infringe privately owned rights. Reference herein to any specific commercial product, process, or service by trade name, trademark, manufacturer, or otherwise does not necessarily constitute or imply its endorsement, recommendation, or favoring by the United States Government or any agency thereof. The views and opinions of authors expressed herein do not necessarily state or reflect those of the United States Government or any agency thereof. 


\section{DISCLAIMER}

Portions of this document may be illegible in electronic image products. Images are produced from the best available original document. 
JAN 24:97 14:01 FROM ARC-CODE 5

<DIVISION>

ENVIRONMENTAI SCIENCES: GLOBAL CHANGE.

$</ D I V I S I O N>$

<RESEARCH AREA>

ATMOSPHERIC RADIATION MEASUREMENT

$</ R E S B A R C H \cdot A R E A>$

<DOE PROGRAM MANAGER>

P.W. IULNN

</DOE PROGRAM MANAGER>

<ABSTRACTS

</ABSTRACTS

<TITIE>

MODELING OF CIOUDS AND RADIATION FOR DEVEIORING - DE-AIO $3.94 E R 61743$

PARAMETERIZATIONS OF CLOUDS IN GMNERAL CIRCULATION MODELS

C/TITLES

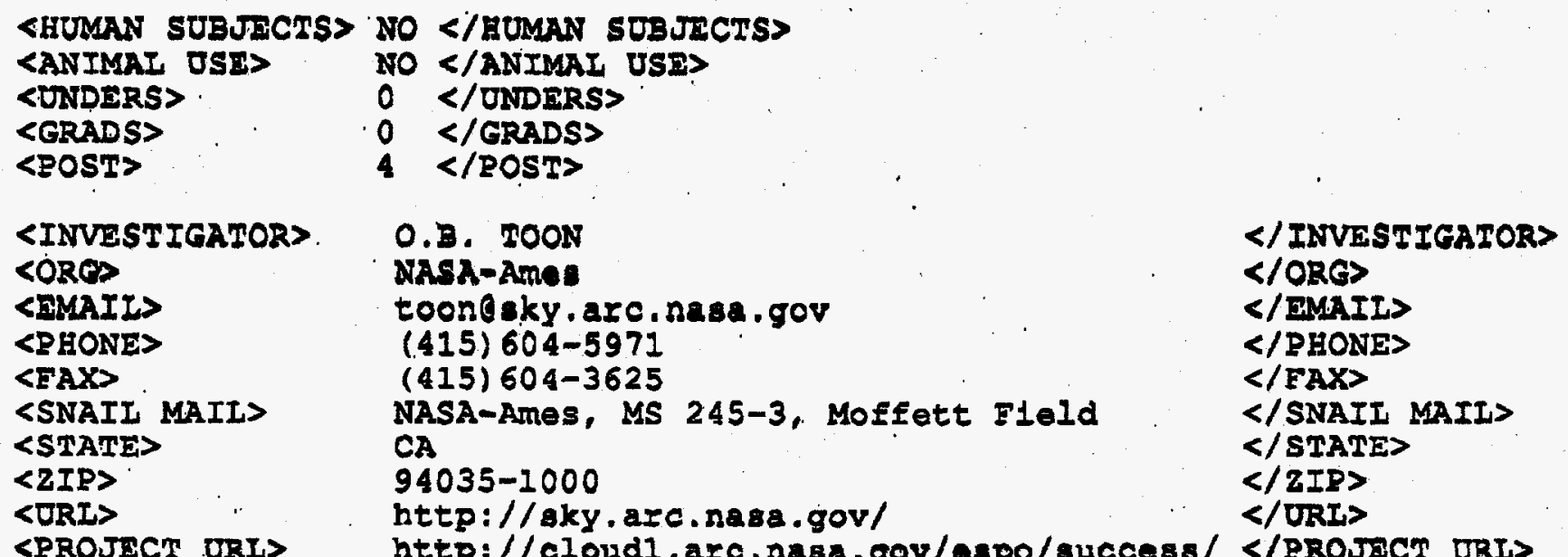

SPROJECT ORI>

http://Cloudl,arc.nasa.gov/espo/auccess/ </RROJXCl JRL>

〈DATES>

EY 1996. 160k <br>

FY 1995 200k <br>

FY 19.94 200k <p>

$</$ DATES $>$

<START DATE> 10/01/94 </START DATE>

<BMD DATE> 30/09/96 </END DATE>

<KEYWORDS>

CIOUD MODELING<br>

RADIATIVE TRANSEER MODEIING<bI>

</KJYWORDS>

<OBUTCTIVE>

We conductod modeling work in radiative transfer and cloud miorophysics. Our work in radiative trander included performinoe tests to other hlgh accuracy methods and to menourements under cloudy, partial eloudy and cloud-free conditions. Our modeling efforts have been aimed to:

<ul>

<li> develop an accurate and rapid radiative transfer model

<li> develop three-dimensionel radiative transfer models

$\langle I 1\rangle$ develop microphystcs resolving cloud and aerosol models

$</$ LI

We applied our models to:

$\langle u l\rangle$

<I1> Investigate solar clear-sky model blases

<I1> Investigate aerosol direct effects 
JAN 24:9? 14:01 FROM ARC-CODE $S$

<Ii> Investigate aerosol Indirect effects

<II> Investigate microphysical properties of cirrug

<I1> Investigate microphysical properties of stratus

<11> Inveatigate relationships between cloud properties

$<l i>$ investigate the effects of cloud structure

$</ u 1\rangle$.

We conducted in April an aircraft fleld program, sUCCEss, over the ARM field site measuring clrrus radiative and microphysical properties for improved radiative transfor and cloud formation simiations.<br $\rangle$

$<$ /OBUSCTIVEs

\section{<APPROACH>}

Most models of clouds have fooused on cloud dynamics. This is not adequate if we wish to have an improved understanding of cloud radiative properties. The radiative properties of clouds depend on particle size distribution, cloud water or 1 ce content, and the distributions of these properties through the clouds. Microphysical cloud modeis in which the drop size distribution 18 resolved and macrophysical cloud modelis that account for the oloud etructural geometry are required to calculate such quantities. Sbr>

Recently masurements have euggested that alouds absorb moze solar radiation than proviously uspocted and wo investigeted this 1ssue For marine etratus clouds and for horlzontal inhomgeneity of clouds, which in generally overlooked in radiative transfer models. <br>

Our comparion between fleld obnervitions and model results for cirrus cloud reveled that now efforts in radiutive transfor modoling are necessery to dexi with oloud inhomgeneity offects <br>

Ho developed now 3-dimensional radiative transfer codes, a Monte-Carlo code and time-effletent $1 \mathrm{ix}$-stream mothod, to understand the effects of cloud lahomogeneity on (solar) radiative transfer.<br> We also have continued the development of a rapid radiative transfer model (3-ARM) for use in climate simulations. The model is a joint effort between NASA-Ames, AER and the Pennsylvania state University.

The model combines the efficient 2-stream code of roon et.al. 1989, new k-distributione for gas-absorption from AJR and a new 4-stream option from Penn State. $\langle b x\rangle$

We also conflrmed recent concerns about the poor pexformance of solar. radiative transfer modelo under cloud-free sonditions with our models and we are currently looking for an explanation. It is imperative to understand th1s clear sky modeling problem before progresg can be made for comparisons under cloudy condittons : <br>

In addition to our work on microphysics and radiative trangfer, we have also been active in the deatgn of fleld programs to provide data which Improves our underatanding of cloud radiative properties. For 1natance the NASA eponsored soCCESS 11eld program, in April and early May 1996, provided for eleven days observations of detailed cloud in-situ microphysical data and radiative measurements over and near the DOE-CART site. These measurements complement not only observations at the ground (DOE ARM CART-site), they also complement measurements by the DOE UAV program, which was conductad at the same time. A large sraction of our group particpated in success either. as project scientists, alrcraft scientists, or theory team members. $</$ APPROACES

\section{<RESULTS TO DATE>}

Results for clear-sky conditions:

<ul>

<II> current radiative transfer models consistently overpredict the solar radlative flux reaching the surface: aerosol measurements, water vapor data and good agreement for the direct solar insolation, eliminate easy explanations

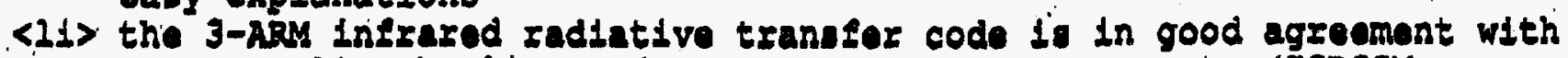
</uls accurate line-by-1ine coder and DOI AERI measurement (ICRCCM comparison)

Resilts for cloudy condltions:

$\langle l i>$ increased cloud inhomogeneity increases the transmission and reduces 
JAN 24 ' 97 14:02 FROM ARC-CODE 5

- the. reflection and absorption

<il> overlooked cloud inhomogenelty is. unlikely to explain measurements of excess solar absorption

<11> 3D six-stream methods can be an excellent tool to gulckly 1llustrate scattering patterns for 1nhomgeneous media

<i1> excess solar absorption in marine stratus must be negligible - otherwise these clouds would not exist

<I1> for cirrus, it is almost impossible to find unique relationships between $\langle/ 43>$ two properties unless at leest a third cirrus properties is considered

</RESULTS TO DATE>

<DEIIVIRABLES>

Below we 11st the published papers that have been prepared under partial oupport. Irom ARM during the previous proposal perlod. Our work has been focuaed on providing more dotalled microphysical modele of cloude than have been avallable previously, lnvestigating the indirect and direct effects of aerosols on climete, understanding the radiative properties of clouds, and developing improved techniques for performing radiative transfer calculations.<p>

"Cirxus microphysics and radiative transfer: cloud fleld study on 28 October 1986" (Rinne, S., T.P. Ackeman, A.J. Heymsfield, E.P.J. Valero, K. Sassen, and J.D. SpInhirne), Mon. Wea. Rev., 120, 661-684, 1992. $\langle$ bry

"The potential effeots of volcanic aerosols on cirrus eloud microphysics" (E.J. Jensen, and O.B. Toon), Geophys: Res. Iott., 19, 1759-1762 (1992). $\langle b x>$

"Dissipation of Marine strat1form oloude and collapse of the marine boundary layer due to aerosol depletion by olouds", (A.S. Ackerman, 0.B. Toon, and P.V. Hobbs) Setenoe, 262, 226-229 (1993).

$\langle$ br>

"Modeling coagulation among particles of different composition and size" (M.z. Jacobson, R.P. Turco, E.J. Jensen, and O,B. Toon, Atmos. Environ. $28,1327-1338(1994)$.

<br>

"Ice nucleat1on in the upper troposphere: Sensitivity to aerosol number density, temperature, and cooling rate" (I.J. Jensen and 0.B. Toon), Geophys. Res. Lett., 21, 2019-2022 (1994).

$\langle\mathrm{br}>$

"Resseosing the dependence of cloud condensation nucleus concentrations on formation rate" (A.S, Ackerman, 0.B. Toon, and P.V. Lobbs), Nature 367,445-447 (1994).

$\langle$ brs

"Troplcal clrrus cloud radiative forcing: Sensitivity studies" (E.J. Jensen, S. Kinne, and O.B. Toon), Geophys. Res. Lett., 21, 2023-2026 (1994). $\langle$ brs

- Microphystcal modeling of cirrus 1: Comparison with 1986 FIRE IFo measurements.' (Z.J.' Jensen, O.B. Toon, D.I. Westphal, S. Rinne, and A.J. Eeymafleld), J. Goophys. Res. 99; 10421-10442 (1994).

<pr>

"Microphysical modeling of cirrus 2. Sensitivity studies". (I.J. Jensen, 0. B. Toon, D.L. Westphal, S. Kinne, and A.J. Heymsfield), J. Geophys. Res.., 99 10443-10454 (1994).

$\langle$ br>

"A model for particle microphysics, turbulent mixing, and radiative transfer in the stratocumulus-topped marine boundary layex and compar1sons with masurements" (A.S. Ackerman, O.B. Toon, and R.V. Hobb8), J. Atmos. Sc1., 52, 1204-1236 (1995).

<br>

"On the formation and persistence of subvisible cirrus clouds near the tropical tropopause" (J.J. Jensen, O.B. Toon, H.B. Selkirk and J. Spinhirne) J. Geophys. Res. in press, (1995). $\langle$ br>

Modeling the relationshlps between aerosol properties and the direct and indirect effects of aerosols on climate" (O.B. Toon) in Aerosol Eorcing 
- JAN é4. 9 14:03 FROM ARC-CODE 5

of Climate DahIem Workshop Report as 17, ed. R.J. Charlson and J. Eelntzenberg, $J$. Wileý sons; pg 197-213, (1995). <br>.

"Numerical modeling of ahip tracks produced by injections of cloud condensation nucle into marine stzatiform cloude" (A.S. Aokerman, O.B. Toon, and P.V. Hobbs) J. Geophys. Res., 100, 7121-7134 (1995). <br>

"The Impact of enhanced solar absorption on model simulations of the cloud-topped marlne boundary layer" (A.S. Ackerman and 0.B. Toon)

Nature, in Press, (1996).

$\langle$ bri

"Where to look for the effecte of aerovol pollution on aloud albedon ( $A$. Ackerman, O.B. Toon, P.V. Hobba) Natuxe, ubindtted, 1996.

<br>

"Dlrect radiative forcing by anthropogente airborne mineral aerosols" (I. Sokolik and O. B. Toon), Nature, submitted, (1996). $\langle$ br>

"Dehydration of the upper troposphere and lower stratoopheze by eubvistble olrrue cloude near the tropleal tropopause" (I.J. Jansen, Ons. Toon, I.e. SFinter, and H. Selkirk), Geophye. Res. Latt., In gresa (1996). $\langle$ br>

"Clrzus cloud radiative and mlcrophyalcal properties from ground observations and In-situ measurements during FIR3-91 and their application to exhiblt problems in cirrug solar radiative tranefer" (S. Rinne, T.P. Ackerman, M. Shlobara, A. Uchiyama, A.J. Heymsfield, I. Miloshevich, J. Wendell, E. Bloranta, C. Purgold and R.w. Bergstrom). J.Atmos.sc1. submitted, (1996) $\langle$ brs

"Inftialization and validation of eimulation of olrrug using rIRE-II data" (D.I. Weatphal, S. Xinne, J.M. Alvares, S.G. Benjamin, W.I. Eberhard, A.J. Heymafleld, R.A: KropfI1, G.G. Mace, S.Y. Matrosov, S.h. Mele1, P. Minnte, P. Rllewgkie, J.A. Snider, B.J. Sodon, D.O'C. Starr, T.A. Uttal, D.F. Young). J. Atmos. Sc1. submitted, (1996). $\langle p\rangle$

Abstracts of papers given at the 1996 ARM Science team meeting:

$\langle\mathrm{br}\rangle$

"3ARM - A fagt accurate radiative tranater modal for the use in climate codes". (Bergatrom, R, S. Rinne, B. Toon, B. Mlawer, S.A. Clough, T. Ackerman, T,Mather) <br>

"Solar radiative transfer modeling under cloud-free conditlons"

(K1nne, S, R.T. Bergstrom, O.B. Toon)

$\langle b r\rangle$

"3-D scattering simulations for clouds: How accurate la the six-atream mothod?" (S. Kinne, R.W. Bergatrom, O.B. Toon)

</DELIVERABIES>

<SYSTEMDATE>

Sat Jun 29. 20:00:00 EST 2996

</SYSTEMDATES 